Keywords: Sludge Batch 7, DWPF, Analytical, Characterization, Tank 4, Tank 12

Retention: Permanent

\title{
Sludge Batch 7 Preparation: Tank 4 and 12 Characterization
}

\author{
C. J. Bannochie \\ D. R. Click \\ J. M. Pareizs
}

May 2010

Savannah River National Laboratory Savannah River Nuclear Solutions Aiken, SC 29808 
SRNL-STI-2010-00223

Revision 0

\section{DISCLAIMER}

This work was prepared under an agreement with and funded by the U.S. Government. Neither the U.S. Government or its employees, nor any of its contractors, subcontractors or their employees, makes any express or implied:

1. warranty or assumes any legal liability for the accuracy, completeness, or for the use or results of such use of any information, product, or process disclosed; or

2. representation that such use or results of such use would not infringe privately owned rights; or

3. endorsement or recommendation of any specifically identified commercial product, process, or service.

Any views and opinions of authors expressed in this work do not necessarily state or reflect those of the United States Government, or its contractors, or subcontractors.

\section{Printed in the United States of America}

Prepared for

U.S. Department of Energy 


\section{REVIEWS AND APPROVALS}

\section{AUTHORS:}

C. J. Bannochie, Process Technology Programs

Date

D. R. Click, Analytical Development

Date

J. M. Pareizs, Process Technology Programs

Date

TECHNICAL REVIEW:

D. P. Lambert, Process Technology Programs

Date

APPROVAL:

C. C. Herman, Manager

Date

Process Technology Programs

Date

S.L. Marra, Manager

Environmental \& Chemical Process Technology Research Programs

D. C. Bumgardner, Manager

Date

Tank Farm Engineering 


\section{ACKNOWLEDGEMENTS}

The authors acknowledge the SRNL Shielded Cells technicians and management whose efforts facilitated the timely processing of these sludge samples. 
SRNL-STI-2010-00223

Revision 0

\section{EXECUTIVE SUMMARY}

Samples of PUREX sludge from Tank 4 and HM sludge from Tank 12 were characterized in preparation for Sludge Batch 7 (SB7) formulation in Tank 51. SRNL analyses on Tank 4 and Tank 12 were requested in separate Technical Assistance Requests (TAR). ii $\quad$ The Tank 4 samples were pulled on January 19, 2010 following slurry operations by F-Tank Farm. The Tank 12 samples were pulled on February 9, 2010 following slurry operations by H-Tank Farm.

At the Savannah River National Laboratory (SRNL), two $200 \mathrm{~mL}$ dip samples of Tank 4 and two $200 \mathrm{~mL}$ dip samples of Tank 12 were received in the SRNL Shielded Cells. Each tank's samples were composited into clean $500 \mathrm{~mL}$ polyethylene storage bottles and weighed. The composited Tank 4 sample was 428.27 $\mathrm{g}$ and the composited Tank 12 sample was $502.15 \mathrm{~g}$.

As expected there are distinct compositional differences between Tank 4 and Tank 12 sludges. The Tank 12 slurry is much higher in $\mathrm{Al}, \mathrm{Hg}, \mathrm{Mn}$, and $\mathrm{Th}$, and much lower in Fe, Ni, S, and $\mathrm{U}$ than the Tank 4 slurry.

The Tank 4 sludge definitely makes the more significant contribution of $\mathrm{S}$ to any sludge batch blend. This S, like that observed during SB6 washing, is best monitored by looking at the total S measured by digesting the sample and analyzing by inductively coupled plasma - atomic emission spectroscopy (ICPAES). Alternatively, one can measure the soluble S by ICP-AES and adjust the value upward by approximately $15 \%$ to have a pretty good estimate of the total $\mathrm{S}$ in the slurry. Soluble sulfate measurements by ion chromatography (IC) will be biased considerably lower than the actual total S, the difference being due to the non-sulfate soluble $\mathrm{S}$ and the undissolved S.

Tank 12 sludge is enriched in U-235, and hence samples transferred into SRNL from the Tank Farm will need to be placed on the reportable special nuclear material inventory and tracked for total U per SRNL procedure requirements.

i. Colleran, H. Q. Tank 4 Slurry Samples in Support of Sludge Batch 7 Preparation, 2010-LWOTF-002, Rev. 0, Savannah River Site, Aiken, SC 29808 (2010).

ii. Martin, K. B. Tank 12 Slurry Samples in Support of Sludge Batch 7 (SB7), 2010-LWOTF-001, Rev. 0, Savannah River Site, Aiken, SC 29808 (2010). 


\section{TABLE OF CONTENTS}

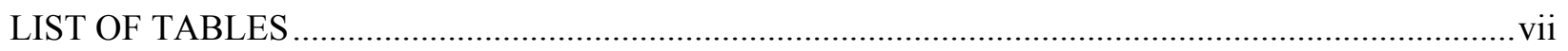

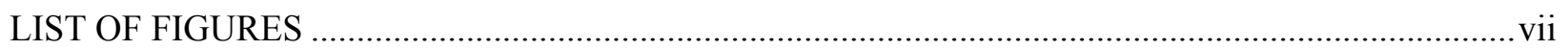

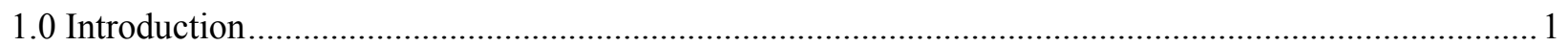

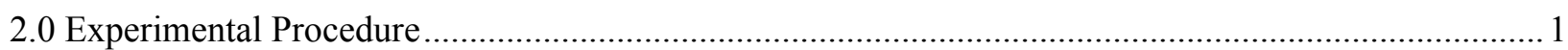

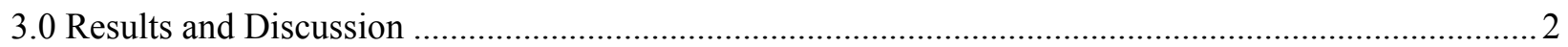

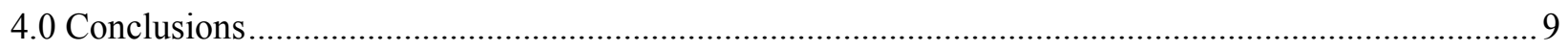

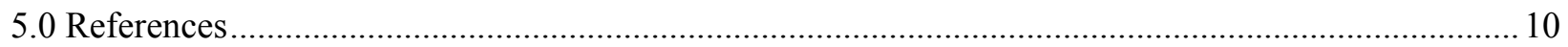


SRNL-STI-2010-00223

Revision 0

\section{LIST OF TABLES}

Table 2-1. MV I Rotor Specifications and Flow Curve Program .......................................................... 2

Table 3-1. Densities and Weight Percent Solids for the Tank 4 and Tank 12 SB7 Preparation Samples.... 3

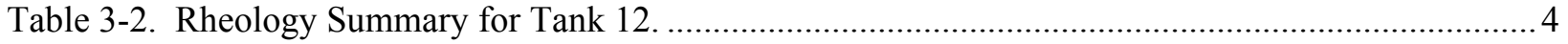

Table 3-3. Concentrations of Elements in Total Dried Solids for the Tank 4 and Tank 12 SB7 Preparation Samples. Results are Averages of Dissolution and Analysis of Three to Eight Aliquots of the Respective Slurry. 5

Table 3-4. Concentrations of Noble Metals and Silver in Total Dried Solids for the Tank 4 and Tank 12 SB7 Preparation Samples. Results are Averages of Aqua Regia Digestions and ICP-MS Analyses of

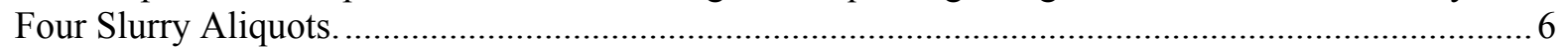

Table 3-5. Concentrations of Soluble Elements for the Tank 4 and Tank 12 SB7 Preparation Samples. Results are Averages of Four Supernate Aliquots ............................................................................... 7

Table 3-6. Concentrations of Anions on a Supernate Basis for the Tank 4 and Tank 12 SB7 Preparation Samples. Results are Averages of Four Supernate Aliquots............................................................. 7

Table 3-7. Uranium Isotopes in Tank 4 and Tank 12 SB7 Preparation Samples. Results are Averages of

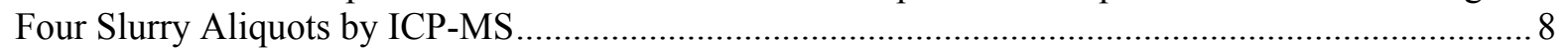

\section{LIST OF FIGURES}

Figure 3-1. Tank 12 Shear Stress vs. Shear Rate Replicate 1 .............................................................. 3

Figure 3-2. Tank 12 Shear Stress vs. Shear Rate Replicate 2 …........................................................... 4

Figure 3-3. Sulfur and Sulfate Measured During the SRNL SB6 Qualification Sample Washing............. 8 


\section{LIST OF ABBREVIATIONS}

$\begin{array}{ll}\text { AD } & \text { Analytical Development } \\ \text { CVAA } & \text { Cold Vapor Atomic Absorption Spectroscopy } \\ \text { DOE } & \text { Department of Energy } \\ \text { DWPF } & \text { Defense Waste Processing Facility } \\ \text { g } & \text { gram } \\ \text { HM } & \text { H-Area Modified PUREX } \\ \text { ICP-AES } & \text { Inductively Couple Plasma - Atomic Emission Spectroscopy } \\ \text { ICP-MS } & \text { Inductively Coupled Plasma - Mass Spectrometry } \\ \text { L } & \text { liter } \\ \text { PUREX } & \text { Plutonium Uranium Reduction Extraction } \\ \text { SB6 } & \text { Sludge Batch 6 } \\ \text { SB7 } & \text { Sludge Batch 7 } \\ \text { SNRL } & \text { Savannah River National Laboratory } \\ \text { SRS } & \text { Savannah River Site } \\ \text { TAR } & \text { Technical Assistance Request } \\ \text { Wt\% TS } & \text { Weight Percent of Total Solids }\end{array}$


SRNL-STI-2010-00223

Revision 0

\subsection{Introduction}

Samples of PUREX sludge from Tank 4 and HM sludge from Tank 12 were characterized in preparation for Sludge Batch 7 (SB7) formulation in Tank 51. SRNL analyses on Tank 4 and Tank 12 were requested in separate Technical Assistance Requests (TAR). ${ }^{1,2}$ The Tank 4 samples were pulled on January 19, 2010 following slurry operations by F-Tank Farm. The Tank 12 samples were pulled on February 9, 2010 following slurry operations by H-Tank Farm.

\subsection{Experimental Procedure}

At the Savannah River National Laboratory (SRNL), two $200 \mathrm{~mL}$ dip samples of Tank 4 and two $200 \mathrm{~mL}$ dip samples of Tank 12 were received in the SRNL Shielded Cells. Each tank's samples were composited into clean $500 \mathrm{~mL}$ polyethylene storage bottles and weighed. The composited Tank 4 sample was 428.27 $\mathrm{g}$ and the composited Tank 12 sample was $502.15 \mathrm{~g}$.

Eight separate aliquots of the slurry were digested, four with $\mathrm{HNO}_{3} / \mathrm{HCl}$ (aqua regia ${ }^{3}$ ) in sealed Teflon ${ }^{\circledR}$ vessels and four in $\mathrm{Na}_{2} \mathrm{O}_{2}$ (alkali or peroxide fusion ${ }^{4}$ ) using $\mathrm{Zr}$ crucibles. Due to the use of $\mathrm{Zr}$ crucibles and $\mathrm{Na}$ in the peroxide fusions, $\mathrm{Na}$ and $\mathrm{Zr}$ cannot be determined from this preparation. Additionally, other alkali metals, such as $\mathrm{Li}$ and $\mathrm{K}$, and alkaline earth metals, such as $\mathrm{Ca}$, that may be contaminants in the $\mathrm{Na}_{2} \mathrm{O}_{2}$ are not determined from this preparation. Three Analytical Reference Glass $-1^{5}$ (ARG-1) standards were digested along with a blank for each preparation. The ARG-1 glass allows for an assessment of the completeness of each digestion. Each aqua regia digestion and blank was diluted to 1:100 mL with deionized water and submitted to Analytical Development (AD) for inductively coupled plasma - atomic emission spectroscopy (ICP-AES) analysis, inductively coupled plasma - mass spectrometry (ICP-MS) analysis of masses 81-209 and 230-252, and cold vapor atomic absorption (CVAA) analysis for $\mathrm{Hg}$. Equivalent dilutions of the peroxide fusion digestions and blank were submitted to AD for ICP-AES analysis.

Tank 4 and 12 supernate was collected with a $0.45 \mu \mathrm{m}$ filter cup from a mixed slurry sample in the SRNL Shielded Cells and submitted to AD for ICP-AES and ion chromatography (IC).

Rheological properties of radioactive samples are determined using a Haake M5/RV30 rotoviscometer. The M5/RV30 is a Searle sensor system, where the bob rotates and the cup is fixed. The torque and rotational speed of the bob are measured. Heating/cooling of the cup/sample/bob is through the holder that holds the cup. The shear stress is determined from the torque measurement and is independent of the rheological properties. Conditions that impact the measured torque are; slip (material does not properly adhere to the rotor or cup), phase separation (buildup of a liquid layer on the rotor), sedimentation (particles settling out of the shearing zone), homogeneous sample (void of air), lack of sample (gap not filled), excess sample (primarily impacts rheologically thin fluids), completely filling up the void below the bob (air buffer that is now filled with fluid) and Taylor vortices. The first five items yield lower stresses and the last three add additional stresses. The shear rate is geometrically determined using the equations of change (continuity and motion) and is that for a Newtonian fluid. This assumption also presupposes that the flow field is fully developed and the flow is laminar. The shear rate can be calculated for a non-Newtonian fluid using the measured data and fitting this data to the rheological model or corrected as recommended by Darby ${ }^{6}$. In either case, for shear thinning nonNewtonian fluids typical of Savannah River Site (SRS) sludge wastes, the corrected shear rates are greater than their corresponding Newtonian shear rates, resulting in a thinner fluid. Correcting the flow curves was not performed in this task; therefore, the results are biased high.

The bob typically used for measuring tank sludge is the MV I rotor. The shape, dimensions, and geometric constants for the MV I rotor are provided in Table 2-1. 
Prior to performing the measurements, the rotors and cups were inspected for physical damage. The torque/speed sensors and temperature bath verified for functional operability using a bob/cup combination with a National Institute of Standards and Technology (NIST) traceable Newtonian oil standard, using the MV I rotor. The resulting flow curves were then fitted as a Newtonian fluid with the control being a calculated viscosity within $\pm 10 \%$ of the reported NIST viscosity at a given temperature. A N10 oil standard was used to verify system operability prior to the sludge measurements.

The flow curves for the sludge are fitted to the down curves using the Bingham Plastic rheological model, Equation (1), where $\tau$ is the measured stress $(\mathrm{Pa}), \tau_{\mathrm{o}}$ is the Bingham Plastic yield stress $(\mathrm{Pa}), \mu_{\infty}$ is the plastic viscosity $(\mathrm{Pa} \cdot \mathrm{sec})$, and $\cdot \gamma$ is the measured shear rate $\left(\mathrm{sec}^{-1}\right)$. During all these measurements, the sample remained in the cup for the $2^{\text {nd }}$ measurement, due to the limited sample availability.

$$
\tau=\tau_{o}+\mu_{\infty} \dot{\gamma}
$$

Table 2-1. MV I Rotor Specifications and Flow Curve Program

\begin{tabular}{|c|c|c|}
\hline Rotor Design & \multicolumn{2}{|l|}{ Dimensions and Flow Curve Program } \\
\hline & Rotor Type & MV I \\
\hline & Rotor radius $-\mathrm{R}_{\mathrm{i}}(\mathrm{mm})$ & 20.04 \\
\hline & Cup Radius - $\mathrm{R}_{\mathrm{a}}(\mathrm{mm})$ & 21.0 \\
\hline & Height of rotor $-\mathrm{L}(\mathrm{mm})$ & 60 \\
\hline & Sample Volume $\left(\mathrm{cm}^{3}\right)$ minimum & 40 \\
\hline & A factor $(\mathrm{Pa} / \%$ torque $)$ & 3.22 \\
\hline & $\mathrm{M}$ factor $\left(\mathrm{s}^{-1} / \% \mathrm{RPM}\right)$ & 11.7 \\
\hline & Shear rate range $\left(\mathrm{s}^{-1}\right)$ & $0-600$ \\
\hline & Ramp up time (min) & 5 \\
\hline & Hold time (min) & 1 \\
\hline & Ramp down time (min) & 5 \\
\hline
\end{tabular}

\subsection{Results and Discussion}

Table 3-1 presents the measured Tank 4 and Tank 12 densities and weight percent solids data. ${ }^{7}$ The Tank $^{2}$ 4 results compare quite well with those reported on the previous Tank 4 slurry sample. ${ }^{8}$ Particularly close was the calculated insoluble solids content of the two samples, $3.62 \mathrm{wt} \%$ for the sample taken last summer during SB6 preparations, and $3.64 \mathrm{wt} \%$ for this sample of Tank 4. 
Table 3-1. Densities and Weight Percent Solids for the Tank 4 and Tank 12 SB7 Preparation Samples

\begin{tabular}{|c|c|c|}
\hline Property & $\begin{array}{c}\text { Tank } 4 \text { Result } \\
\text { (\%RSD) }\end{array}$ & $\begin{array}{c}\text { Tank } 12 \text { Result } \\
\text { (\%RSD) }\end{array}$ \\
\hline $\begin{array}{l}\text { Slurry Density } \\
\text { (g/mL) }\end{array}$ & $1.34(0.1) \dagger$ & $1.27(0.9) \ddagger$ \\
\hline $\begin{array}{l}\text { Supernate Density } \\
\qquad(\mathrm{g} / \mathrm{mL})\end{array}$ & $1.32(0.3) \dagger$ & $1.23(0.9) \ddagger$ \\
\hline $\begin{array}{l}\text { Wt } \% \text { Total Solids } \\
\text { (Slurry Basis) }\end{array}$ & $34.5(0.3)$ & $28.8(0.2)$ \\
\hline $\begin{array}{l}\mathrm{Wt} \% \text { Dissolved Solids } \\
\quad \text { (Supernate Basis) }\end{array}$ & $32.0(0.1)$ & $24.9(0.3)$ \\
\hline $\begin{array}{l}\mathrm{Wt} \% \text { Soluble Solids } \\
\quad \text { (Slurry Basis) }\end{array}$ & $30.9(0.1)^{\mathrm{c}}$ & $23.6(0.2)^{\mathrm{c}}$ \\
\hline $\begin{array}{l}\mathrm{Wt} \% \text { Insoluble Solids } \\
\text { (Slurry Basis) }\end{array}$ & $3.64(2.1)^{\mathrm{c}}$ & $5.23(1.2)^{\mathrm{c}}$ \\
\hline $\begin{array}{l}\text { Temperature at time of density me } \\
\text { Temperature at time of density me } \\
\text { llso known as Uncorrected Solubl } \\
\text { lso known as Corrected Soluble S } \\
\text { oRSD here is more correctly defin }\end{array}$ & $\begin{array}{l}\text { thts was } 10^{\circ} \mathrm{C} \text {. } \\
\text { nts was } 16^{\circ} \mathrm{C} \text {. }\end{array}$ & 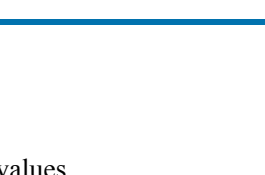 \\
\hline
\end{tabular}

Rheological measurements were made on the Tank 12 material, but not on the Tank 4 material. Previous measurements on Tank $4{ }^{8}$ indicated essentially no yield stress and a plastic viscosity of $6.7 \mathrm{cP}$, and the current sample also appeared to be very thin. Figure 3-1 and Figure 3-2 provide the shear stress versus shear rate flow curves for the Tank 12 sample. The resulting plastic viscosities in $\mathrm{cP}$ and yield stresses in $\mathrm{Pa}$ are summarized in Table 3-2.

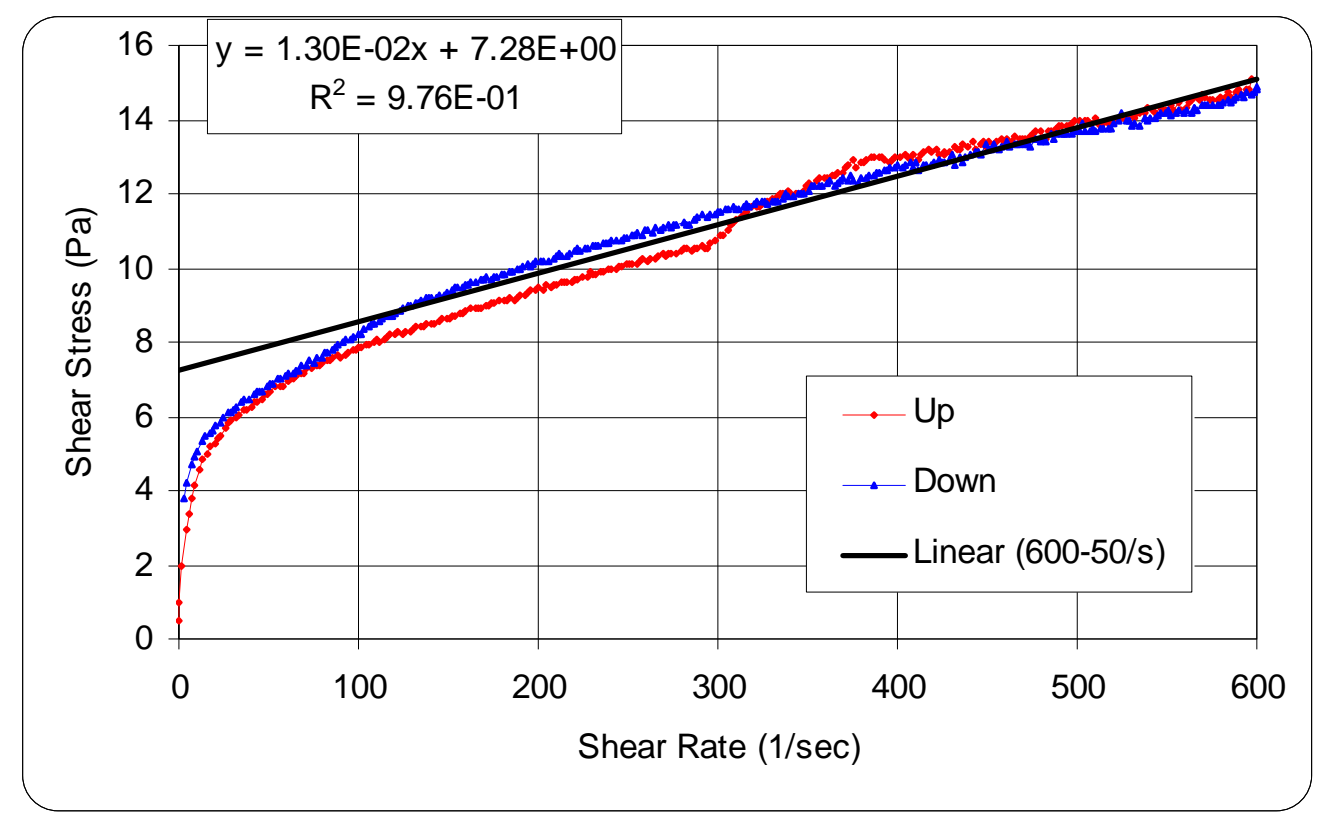

Figure 3-1. Tank 12 Shear Stress vs. Shear Rate Replicate 1 


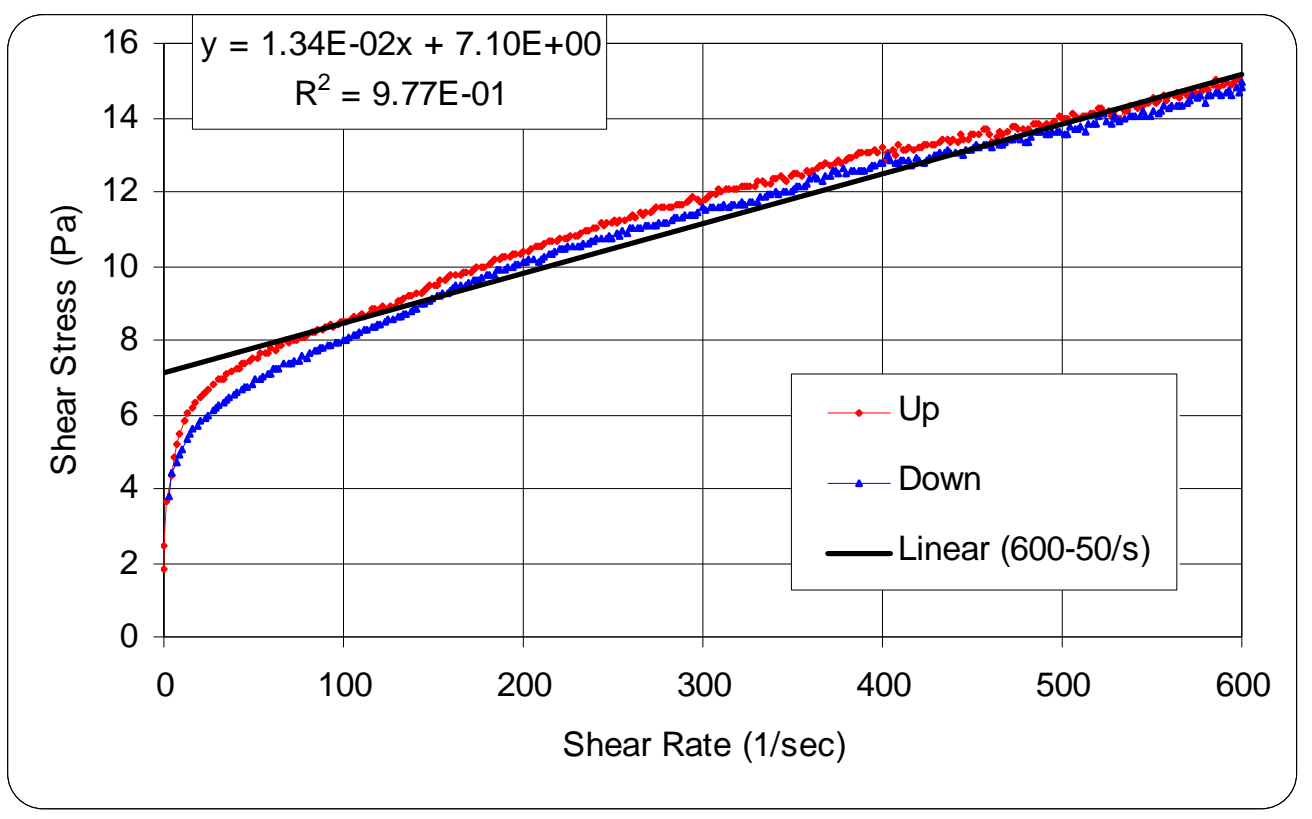

Figure 3-2. Tank 12 Shear Stress vs. Shear Rate Replicate 2

Table 3-2. Rheology Summary for Tank 12.

\begin{tabular}{ccc}
\hline Replicate & Consistency (cP) & Yield Stress (Pa) \\
\hline Run 1 & 13.0 & 7.3 \\
Run 2 & 13.4 & 7.1 \\
Average & 13.2 & 7.2 \\
\hline
\end{tabular}

Table 3-3 provides the elemental composition for both Tank 4 and Tank 12 slurry on a weight percent dried total solids (Wt\% TS) basis. Elemental compositions were determined by digestion of the samples and analyses by ICP-AES, ICP-MS, and CVAA. A less than value is reported for the lowest quantification limit measured for the analyzed set of replicates. For elements determined by ICP-MS, the following isotopes were used for each determination: $\boldsymbol{C d}$ in Tank 4, all isotopes were below their quantification limit, and varied across two orders of magnitude, hence the less than value reported is that from the ICP-AES; for Tank 12, the average for masses 111, 112, and 114 was used since the distribution appeared to be natural. Mass 139 was used for La. Ce was the sum of masses 140 and 142 since it was not a natural distribution. For $\mathbf{G d}$, the sum of masses 155, 156, 157, 158, and 160 was used since it was not a natural distribution. For $\boldsymbol{P b}$, the average for masses 206, 207, and 208 was used since the distribution appeared to be natural. Th was determined from mass 232 since mass 230 was below the quantification limit. $U$ was determined from the sum of masses 233, 234, 235, 236, and 238 since it was not a natural distribution. 
Table 3-3. Concentrations of Elements in Total Dried Solids for the Tank 4 and Tank 12 SB7 Preparation Samples. Results are Averages of Dissolution and Analysis of Three to Eight Aliquots of the Respective Slurry

\begin{tabular}{|c|c|c|c|c|c|c|c|}
\hline Element & $\begin{array}{c}\text { Tank } 4 \\
\text { Wt\% Total } \\
\text { Solids } \\
\end{array}$ & $\%$ RSD & $\begin{array}{c}\text { Prep } \\
\text { Method }\end{array}$ & $\begin{array}{c}\text { Tank } 12 \\
\text { Wt\% Total } \\
\text { Solids }\end{array}$ & \%RSD & $\begin{array}{c}\text { Prep } \\
\text { Method }\end{array}$ & Instrument \\
\hline Al & 2.23 & 1.7 & $\mathrm{PF}$ & 7.83 & 9.3 & $\mathrm{PF}$ & ICP-AES \\
\hline $\mathbf{B}$ & 0.0105 & 3.1 & AR & 0.0221 & 5.9 & $\mathrm{AR} / \mathrm{PF}$ & ICP-AES \\
\hline $\mathbf{B a}$ & 0.0207 & 2.7 & $\mathrm{AR} / \mathrm{PF}$ & 0.0123 & 6.9 & $\mathrm{AR} / \mathrm{PF}$ & ICP-AES \\
\hline $\mathbf{B e}$ & $<0.00054$ & - & AR & $<0.00057$ & - & AR & ICP-AES \\
\hline Ca & 0.117 & 1.1 & $\mathrm{AR}$ & 0.0580 & 1.7 & $\mathrm{AR}$ & ICP-AES \\
\hline Cd & $<0.0022 *$ & - & $\mathrm{AR}$ & 0.00105 & 19 & AR & ICP-MS \\
\hline Ce & 0.0277 & 0.8 & $\mathrm{AR}$ & 0.0189 & 1.6 & AR & ICP-MS \\
\hline Co & 0.00286 & 2.3 & AR & $<0.0019$ & - & AR & ICP-AES \\
\hline $\mathrm{Cr}$ & 0.0936 & 2.7 & $\mathrm{AR} / \mathrm{PF}$ & 0.0347 & 5.6 & $\mathrm{AR} / \mathrm{PF}$ & ICP-AES \\
\hline $\mathbf{C u}$ & 0.00770 & 1.4 & AR & $0.0110 \dagger$ & 0.0 & AR & ICP-AES \\
\hline $\mathbf{F e}$ & 3.46 & 1.7 & $\mathrm{AR} / \mathrm{PF}$ & 1.37 & 8.9 & $\mathrm{AR} / \mathrm{PF}$ & ICP-AES \\
\hline Gd & 0.00131 & 1.4 & AR & 0.000776 & 2.5 & AR & ICP-MS \\
\hline Hg & 0.0374 & 3.8 & AR & 0.760 & 7.5 & AR & CVAA \\
\hline $\mathbf{K}$ & 0.165 & 1.3 & $\mathrm{AR}$ & 0.280 & 2.8 & $\mathrm{AR}$ & ICP-AES \\
\hline $\mathbf{L a}$ & 0.0147 & 2.1 & $\mathrm{AR}$ & 0.00941 & 3.9 & $\mathrm{AR}$ & ICP-MS \\
\hline $\mathbf{L i}$ & 0.00252 & 4.2 & $\mathrm{AR}$ & $<0.0062$ & - & $\mathrm{AR}$ & ICP-AES \\
\hline Mg & 0.0121 & 4.8 & $\mathrm{AR} / \mathrm{PF}$ & 0.0223 & 13 & $\mathrm{AR} / \mathrm{PF}$ & ICP-AES \\
\hline Mn & 0.165 & 2.9 & $\mathrm{AR} / \mathrm{PF}$ & 0.906 & 5.3 & $\mathrm{AR} / \mathrm{PF}$ & ICP-AES \\
\hline Mo & 0.0143 & 2.6 & AR & 0.0115 & 4.0 & AR & ICP-AES \\
\hline $\mathrm{Na}$ & 34.3 & 1.1 & AR & 31.1 & 2.0 & AR & ICP-AES \\
\hline $\mathbf{N i}$ & 0.900 & 2.5 & $\mathrm{AR} / \mathrm{PF}$ & 0.116 & 6.9 & $\mathrm{AR} / \mathrm{PF}$ & ICP-AES \\
\hline $\mathbf{P}$ & 0.0825 & 3.5 & AR & 0.0634 & 1.9 & AR & ICP-AES \\
\hline $\mathbf{P b}$ & 0.00408 & 9.0 & AR & 0.00129 & 12 & AR & ICP-MS \\
\hline $\mathbf{S}$ & 3.67 & 2.9 & $\mathrm{AR} / \mathrm{PF}$ & 0.440 & 6.6 & AR & ICP-AES \\
\hline Sb & $<0.017$ & - & AR & $<0.011$ & - & AR & ICP-AES \\
\hline Si & 0.155 & 6.8 & $\mathrm{PF}$ & 0.244 & 14 & $\mathrm{PF}$ & ICP-AES \\
\hline Sn & $<0.028$ & - & AR & $<0.011$ & - & AR & ICP-AES \\
\hline $\mathrm{Sr}$ & 0.00766 & 4.6 & $\mathrm{AR} / \mathrm{PF}$ & 0.00557 & 5.7 & $\mathrm{AR} / \mathrm{PF}$ & ICP-AES \\
\hline $\mathbf{T i}$ & $<0.0039$ & - & AR & 0.00227 & 12 & $\mathrm{AR} / \mathrm{PF}$ & ICP-AES \\
\hline Th & $<0.00068$ & - & AR & 0.589 & 2.3 & $\mathrm{AR}$ & ICP-MS \\
\hline $\mathbf{U}$ & 0.995 & 2.1 & AR & 0.256 & 1.7 & AR & ICP-MS \\
\hline $\mathbf{V}$ & $<0.0039$ & - & $\mathrm{AR}$ & $<0.0042$ & - & $\mathrm{AR}$ & ICP-AES \\
\hline Zn & $<0.0060$ & - & AR & 0.00619 & 1.8 & AR & ICP-AES \\
\hline Zr & 0.0467 & 1.5 & AR & 0.0271 & 2.5 & AR & ICP-AES \\
\hline
\end{tabular}

* The Tank $4 \mathrm{Cd}$ value is reported from ICP-AES because all ICP-MS isotopic values were also below their quantification limit. $\dagger$ Reported result is the average of two replicates.

ICP-MS $\equiv$ inductively coupled plasma - mass spectrometry, ICP-AES $\equiv$ inductively coupled plasma - atomic emission spectroscopy, $\mathrm{CVAA} \equiv$ cold vapor atomic absorption spectroscopy, $\mathrm{AR} \equiv$ aqua regia digestion, $\mathrm{PF} \equiv$ peroxide fusion digestion

Surveying the results given in Table 3-3, the Tank 12 slurry is much higher in $\mathrm{Al}, \mathrm{Hg}, \mathrm{Mn}$, and Th, and much lower in Fe, Ni, S, and U than the Tank 4 slurry. Not unexpected for a HM sludge (Tank 12) versus 
a PUREX sludge (Tank 4). Typically, a value for $\mathrm{S}$ above the quantification limit from the peroxide fusion digestion is not obtained, but for this set of Tank 4 digestions, a value was obtained. The result was consistent with that obtained from the aqua regia digestion. Both preparations were averaged and reported for the Tank 4 slurry.

The fission product noble metal and silver concentrations for both Tank 4 and Tank 12 sludge are given in Table 3-4. The values were calculated from the ICP-MS data using an Excel spreadsheet. This spreadsheet uses the fission yield for each isotope to account for the mass contribution from isotopes in the tank that could not be measured because isotopes of natural $\mathrm{Cd}$ interfere at this mass. An example of this is the measurement at mass 110 , which is comprised of Pd-110 and Cd-110. The uncertainties were analyzed using statistical techniques appropriate for replicate measurements of non-highly correlated data.

Table 3-4. Concentrations of Noble Metals and Silver in Total Dried Solids for the Tank 4 and Tank 12 SB7 Preparation Samples. Results are Averages of Aqua Regia Digestions and ICP-MS Analyses of Four Slurry Aliquots.

\begin{tabular}{ccccc}
\hline Element & $\begin{array}{c}\text { Tank 4 } \\
\text { Wt\% Total Solids }\end{array}$ & \%RSD & $\begin{array}{c}\text { Tank 12 } \\
\text { Wt\% Total Solids }\end{array}$ & \%RSD \\
\hline Ru & 0.0243 & 0.6 & 0.0119 & 1.2 \\
Rh & 0.00549 & 2.4 & 0.00257 & 5.2 \\
Pd & 0.00171 & 1.4 & 0.000598 & 4.6 \\
Ag & 0.0150 & 2.0 & 0.00279 & 2.2 \\
\hline
\end{tabular}

The soluble elemental, i.e. those in the supernate, values above the quantification limit are provided in Table 3-5. While Fe was detected in three replicates in the Tank 12 sample, there was considerable scatter in the results. Iron was not detected at all in the Tank 4 supernate. The most significant difference is the difference in the $\mathrm{S}$ values between the two tanks. Tank 4, as observed for the total $\mathrm{S}$ value (Table 3-3), has more than an order of magnitude more soluble $\mathrm{S}$ as compared to Tank 12. 
Table 3-5. Concentrations of Soluble Elements for the Tank 4 and Tank 12 SB7 Preparation Samples. Results are Averages of Four Supernate Aliquots

\begin{tabular}{ccclc}
\hline Element & $\begin{array}{c}\text { Tank 4 } \\
\text { Molarity }\end{array}$ & \%RSD & $\begin{array}{l}\text { Tank 12 } \\
\text { Molarity }\end{array}$ & \%RSD \\
\hline Al & 0.345 & 0.1 & 0.268 & 0.4 \\
$\mathbf{B}$ & 0.00252 & 2.0 & 0.00573 & 1.6 \\
$\mathbf{C a}$ & 0.000218 & 6.4 & 0.000135 & 2.5 \\
$\mathbf{C r}$ & 0.00796 & 1.0 & 0.00209 & 0.5 \\
$\mathbf{F e}$ & $\mathrm{ND}$ & - & $0.0000704 \dagger$ & 54 \\
$\mathbf{K}$ & 0.0194 & 2.6 & 0.0274 & 0.9 \\
$\mathbf{M g}$ & $\mathrm{ND}$ & - & $0.0000227 \dagger$ & 3.0 \\
$\mathbf{M o}$ & 0.000722 & 1.4 & 0.000382 & 1.7 \\
$\mathbf{N a}$ & 6.89 & 0.5 & 5.06 & 0.2 \\
$\mathbf{P}$ & 0.00719 & 2.1 & 0.00491 & 1.5 \\
$\mathbf{S}$ & 0.529 & 0.5 & 0.0456 & 2.6 \\
\hline
\end{tabular}

$\mathrm{ND}=$ not detected

$\uparrow$ Reported result is based on three replicates.

Table 3-6 provides the supernate anion concentrations for both Tank 4 and 12 samples determined by IC. Comparing the total soluble S (Table 3-5) with the soluble $\mathrm{S}$ as sulfate (Table 3-6), 4.5\% of the Tank 4 sulfur is present as non-sulfate species, much lower than that seen during SB6 Qualification sample washing in SRNL where the average was $17.5 \%$. The non-sulfate species in Tank 12 accounts for about $18 \%$ of the total soluble S. The Tank 4 material has more than an order of magnitude more soluble $\mathrm{S}$ than does the material in Tank 12.

Converting the soluble $\mathrm{S}$, given in Table 3-6, to a wt\% total solids basis gives a value of $3.61 \mathrm{wt} \% \mathrm{~S}$ for Tank 4 and $0.392 \mathrm{wt} \% \mathrm{~S}$ for Tank 12. Comparing these to the total S determination in Table 3-5 indicates that $<2 \%$ of the Tank 4 total $\mathrm{S}$ is undissolved, while $11 \%$ of the Tank 12 total $\mathrm{S}$ is undissolved. The difference between the soluble $\mathrm{S}$ and sulfate species also varied considerably between the two tank samples. For Tank 4 , the difference is $4.5 \%$ while for Tank 12 the difference is $18 \%$.

Table 3-6. Concentrations of Anions on a Supernate Basis for the Tank 4 and Tank 12 SB7 Preparation Samples. Results are Averages of Four Supernate Aliquots

\begin{tabular}{ccccc}
\hline Anion & $\begin{array}{c}\text { Tank 4 } \\
\text { Molarity }\end{array}$ & \%RSD & $\begin{array}{c}\text { Tank 12 } \\
\text { Molarity }\end{array}$ & \%RSD \\
\hline $\mathbf{B r}^{-}$ & $<0.03$ & - & $<0.02$ & - \\
$\mathbf{C l}^{-}$ & $<0.006$ & - & $<0.05$ & - \\
$\mathbf{F}^{-}$ & $<0.01$ & - & $<0.1$ & - \\
$\mathbf{H C O}_{2}{ }^{-}$ & $<0.005$ & - & $<0.04$ & - \\
$\mathbf{N O}_{3}{ }^{-}$ & 1.13 & 1.6 & 1.11 & 4.8 \\
$\mathbf{N O}_{2}^{-}$ & 0.972 & 0.8 & 1.05 & 0.5 \\
$\mathbf{C}_{2} \mathbf{O}^{2-}$ & $<0.02$ & - & $<0.02$ & - \\
$\mathbf{P O}_{4}{ }^{2-}$ & $<0.02$ & - & $<0.02$ & - \\
$\mathbf{S O}_{4}{ }^{2-}$ & 0.505 & 1.2 & 0.0374 & 1.3 \\
\hline
\end{tabular}

During SB6 Qualification sample washing, about 15\% of the total S as an undissolved species was observed (see Figure 3-3). Note that "undissolved" does not imply that this S cannot dissolve during 
washing operations; it just indicates that it is not soluble under the current sludge conditions. It can also be seen in Figure 3-3 that there is a small, but consistent difference between the soluble S from ICP-AES and the soluble sulfate by IC, expressed in the figure on a molar basis, for the SB6 Qualification sample during washing. This difference averaged $17.5 \%$ (Std. Dev. $2.6 \%$ ) across the eight washes, but the asreceived material did not show any difference between soluble $S$ and sulfate. Hence the difference in soluble $\mathrm{S}$ and sulfate seen during sludge batch washing appears to be due to the contribution of $\mathrm{S}$ from the HM sludge rather than the PUREX sludge.

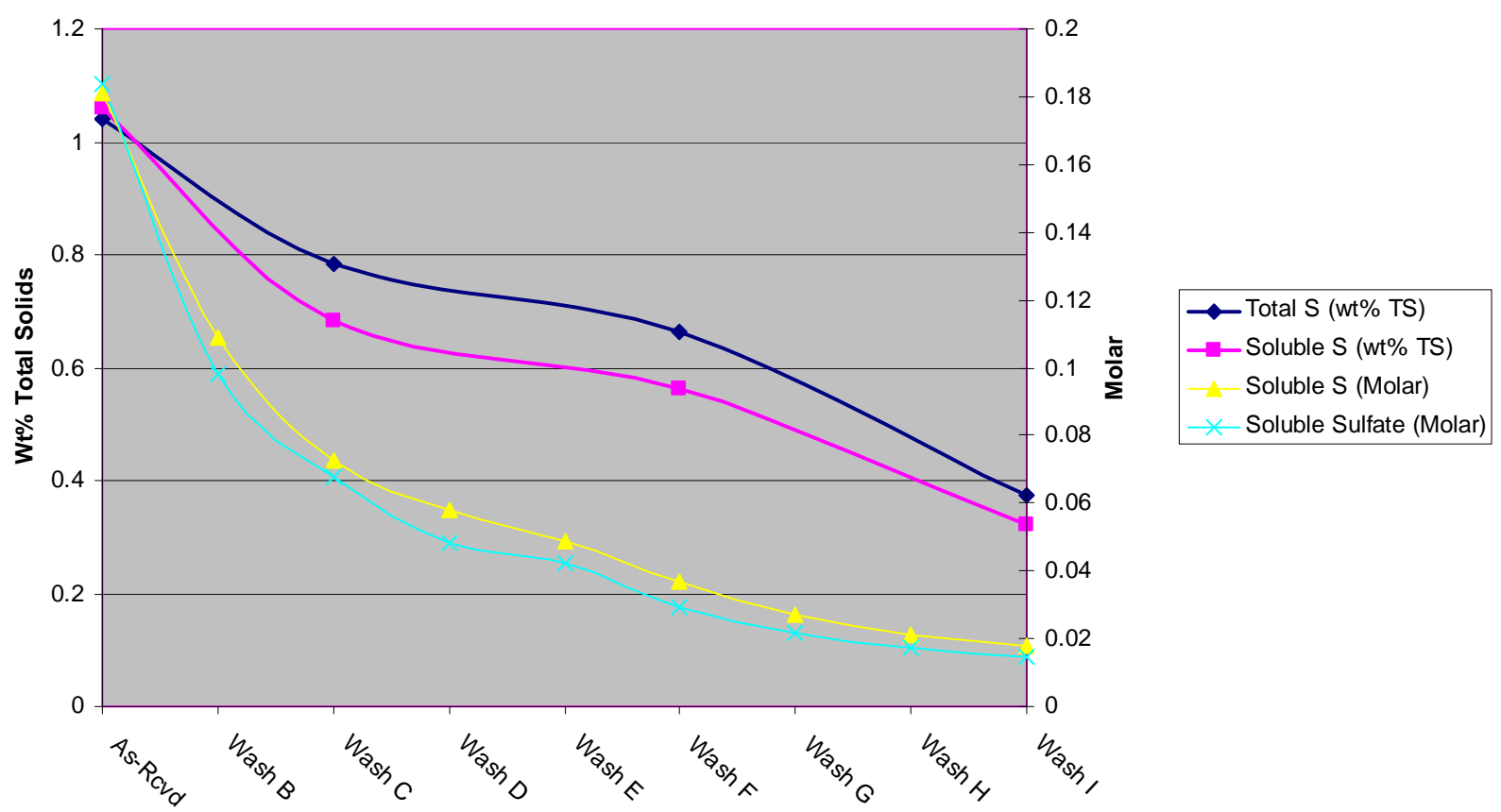

Figure 3-3. Sulfur and Sulfate Measured During the SRNL SB6 Qualification Sample Washing

Table 3-7 provides the isotopic $U$ distribution in terms of $w t \%$ of total solids. Based upon this data, the Tank 4 slurry has a U enrichment of $0.39 \%$, while the Tank 12 slurry has a U enrichment of $0.99 \%$.

Table 3-7. Uranium Isotopes in Tank 4 and Tank 12 SB7 Preparation Samples. Results are Averages of Four Slurry Aliquots by ICP-MS

\begin{tabular}{ccccc}
\hline Isotope & $\begin{array}{c}\text { Tank 4 } \\
\text { Wt\% Total Solids }\end{array}$ & \%RSD & $\begin{array}{c}\text { Tank 12 } \\
\text { Wt\% Total Solids }\end{array}$ & \%RSD \\
\hline U-233 & $<1.3 \mathrm{E}-04$ & - & $2.18 \mathrm{E}-04$ & 19 \\
U-234 & $<6.5 \mathrm{E}-05$ & - & $1.56 \mathrm{E}-04$ & 14 \\
U-235 & $3.83 \mathrm{E}-03$ & 1.0 & $2.52 \mathrm{E}-03$ & 2.4 \\
U-236 & $1.98 \mathrm{E}-04 \dagger$ & 4.7 & $2.59 \mathrm{E}-04$ & 7.5 \\
U-238 & $9.91 \mathrm{E}-01$ & 4.2 & $2.53 \mathrm{E}-01$ & 3.5 \\
\hline
\end{tabular}

$\dagger$ Reported result is based on three replicates. 


\subsection{Conclusions}

As expected there are distinct compositional differences between Tank 4 and Tank 12 sludges. The Tank 12 slurry is much higher in $\mathrm{Al}, \mathrm{Hg}, \mathrm{Mn}$, and $\mathrm{Th}$, and much lower in $\mathrm{Fe}, \mathrm{Ni}, \mathrm{S}$, and $\mathrm{U}$ than the Tank 4 slurry.

The Tank 4 sludge definitely makes the more significant contribution of $\mathrm{S}$ to any sludge batch blend. This S, like that observed during SB6 washing, is best monitored by looking at the total S measured by digesting the sample and analyzing by ICP-AES. Alternatively, the soluble $\mathrm{S}$ can be measured by ICPAES and the value adjusted upward by approximately $15 \%$ to have a pretty good estimate of the total $\mathrm{S}$ in the slurry. Soluble sulfate measurements by IC will be biased considerably lower than the actual total S, the difference being due to the non-sulfate soluble $\mathrm{S}$ and the undissolved $\mathrm{S}$.

Tank 12 sludge is enriched in U-235, and hence samples transferred into SRNL from the Tank Farm will need to be placed on the reportable special nuclear material inventory and tracked for total U per SRNL procedure requirements. 
SRNL-STI-2010-00223

Revision 0

\subsection{References}

1. Colleran, H. Q. Tank 4 Slurry Samples in Support of Sludge Batch 7 Preparation, 2010-LWOTF-002, Rev. 0, Savannah River Site, Aiken, SC 29808 (2010).

2. Martin, K. B. Tank 12 Slurry Samples in Support of Sludge Batch 7 (SB7), 2010-LWOTF-001, Rev. 0, Savannah River Site, Aiken, SC 29808 (2010).

3. Coleman, C. J. Aqua Regia Dissolution of Sludge for Elemental Analysis, Manual L16.1, Procedure ADS-2226, Rev. 9, Savannah River Site, Aiken, SC 29808 (2009).

4. Coleman, C. J. Alkali Fusion Dissolutions of Sludge and Glass for Elemental and Anion Analysis, Manual L16.1, ADS-2502, Rev. 6, Savannah River Site, Aiken, SC 29808 (2008).

5. Smith, G. L. Characterization of Analytical Reference Glass - 1 (ARG-1), PNL-8992, Pacific Northwest (National) Laboratory, Richland, WA (1993).

6. Darby, R. Chemical Engineering Fluid Mechanics, 2nd edition. Marcel Dekker: 2001.

7. Marek, J. C. Correction Factor for Soluble and Insoluble Solids, SRTC-PTD-92-0040, Savannah River Site, Aiken, SC 29808 (1992).

8. Bannochie, C. J., Pareizs, J. M., Click, D. R., and Zamecnik, J. R. Tank 4 Characterization, Settling, and Washing Studies, SRNL-STI-2009-00544, Savannah River Site, Aiken, SC 29808 (2009). 


\section{Distribution:}
A. B. Barnes, 999-W
D. A. Crowley, 773-43A
S. D. Fink, 773-A
B. J. Giddings, 786-5A
C. C. Herman, 999-W
S. L. Marra, 773-A
A. M. Murray, 773-A
F. M. Pennebaker, 773-42A
W. R. Wilmarth, 773-A
D. K. Peeler, 999-W
M. E. Stone, 999-W
N. E. Bibler, 773-A
J. M. Pareizs, 773-A
D. C. Koopman, 999-W
J. R. Zamecnik, 999-W
S. H. Reboul, 773-A
D. R. Click, 773-A

J. M. Gillam, 766-H

B. A. Hamm, 766-H

J. F. Iaukea, 704-30S

D. D. Larsen, 766-H

D. J. McCabe, 773-42A

R. T. McNew, 704-27S

J. E. Occhipinti, 704-S

J. W. Ray, 704-S

H. B. Shah, 766-H

D. C. Sherburne, 704-S

M. A. Broome, 704-29S

J. M. Bricker, 704-27S

T. L. Fellinger, 704-26S

E. W. Holtzscheiter, 704-15S

D. C. Bumgardner, 704-56H

M. T. Keefer, 241-156H

M. D. Buxton, 241-156H

M. Hubbard, 241-162H

H. Q. Colleran, 241-152H

A. W. Wiggins, Jr., 704-60H

C. E. Duffy, 704-61H

D. D. Larsen, 766-H

R. C. Jolly, 704-70F

A. J. Tisler, 704-26F

K. B. Martin, 704-71F 